\title{
Domestication of aromatic medicinal plants in Mexico: Agastache (Lamiaceae)—an ethnobotanical, morpho-physiological, and phytochemical analysis
}

Guadalupe Carrillo-Galván ${ }^{1}$, Robert Bye ${ }^{2^{*}}$, Luis E. Eguiarte ${ }^{3}$, Sol Cristians², Pablo Pérez-López ${ }^{4}$, Francisco Vergara-Silva ${ }^{2}$ and Mario Luna-Cavazos ${ }^{5}$

\begin{abstract}
Background: Most reports of domesticated plants that involve a domestication gradient or inter-specific hybridization in Mexico have focused on those used as food. This study provides knowledge about these processes in two aromatic medicinal plants, Agastache mexicana (Lamiaceae) and A. m. subsp. xolocotziana, widely used in Mexican traditional medicine for the treatment of gastrointestinal ailments and for their sedative effect. Different populations of A. mexicana along a gradient of domestication are found in the foothills of the Popocatepetl volcano of central Mexico, while in this same area the subsp. xolocotziana grows only in the cultivation, possibly a product of hybridization between A. mexicana and Agastache palmeri. This study links ethnobotanical, morphophysiological, and phytochemical evidence to document the domestication of both taxa as well as elucidates the possible hybrid origin of the subsp. xolocotziana.
\end{abstract}

Method: We analyze three groups of data derived from (1) 80 semi-structured interviews aimed at documenting the selection criteria related to the use and management of A. mexicana; (2) a cultivation experiment under homogeneous conditions, evaluating $21 \mathrm{floral}$, vegetative, and seed characters (that were important according to ethnobotanical information) in 97 plants corresponding to 13 populations of the taxa under study; and (3) the chemical profiles of the essential oils of these plants by means of a thin-layer chromatography.

Results: By linking the three types of evidence, two evolutionary processes are distinguished: (1) A. mexicana occurs in the encouraged-cultivated phases of the domestication gradient and (2) A. m. subsp. xolocotziana may have originated through inbreeding depression or hybridization. These two cultivated plants show a domestication syndrome based upon organoleptic differentiation due to their dissimilar phytochemical composition and gigantism in flowers, seeds, and rhizomes (the last enhancing their asexual reproductive capacity). In addition to this, A. mexicana exhibits more intense floral pigmentation and foliar gigantism while subsp. xolocotziana presents floral albinism and partial seed sterility.

(Continued on next page)

\footnotetext{
* Correspondence: bye.robert@gmail.com

2Jardín Botánico, Instituto de Biología, Universidad Nacional Autónoma de México, Ciudad Universitaria, Ciudad de México, México

Full list of author information is available at the end of the article
}

(c) The Author(s). 2020 Open Access This article is licensed under a Creative Commons Attribution 4.0 International License, which permits use, sharing, adaptation, distribution and reproduction in any medium or format, as long as you give appropriate credit to the original author(s) and the source, provide a link to the Creative Commons licence, and indicate if changes were made. The images or other third party material in this article are included in the article's Creative Commons licence, unless indicated otherwise in a credit line to the material. If material is not included in the article's Creative Commons licence and your intended use is not permitted by statutory regulation or exceeds the permitted use, you will need to obtain permission directly from the copyright holder. To view a copy of this licence, visit http://creativecommons.org/licenses/by/4.0/. The Creative Commons Public Domain Dedication waiver (http://creativecommons.org/publicdomain/zero/1.0/) applies to the data made available in this article, unless otherwise stated in a credit line to the data. 


\begin{abstract}
(Continued from previous page)
Conclusion: Two divergent evolutionary processes are reported for the domestication of A. mexicana as a result of the intensification of its use and management. The selection processes of these plants have resulted in alternation of the organoleptic properties based upon the divergence of the phytochemical composition. Also, gigantism has been selected in culturally preferred plant parts and in correlated structures. The preceding characteristics reinforce the joint use of these plants in infusion in Mexican traditionalmedicine for the treatment of gastrointestinal diseases and for their sedative effects.
\end{abstract}

Keywords: Agastache, Domestication, Ethnobotany, Aromatic medicinal plant

\section{Background}

Domestication consists of evolutionary, dynamic, continuous, and multidirectional processes which lead the populations involved to a greater fitness through the selection that the human exerts on them, according to their use and management [1]. The domestication of plants in Mexico involves different degrees along a domestication gradient ranging with four major stages. The wild progenitors receive no conscious human attention, although they may be exploited. The tolerated individuals are allowed to persist usually in anthropogenic habitats contrary to other elements of the vegetation that are eliminated. The encouraged plants are promoted so as to favor the reproduction of the selected individuals with desirable characteristics and are subject to practices that improve to some degree the conditions in which they develop (e.g., protection against competitors and herbivores) [2-7]. Mexican examples include quelites [alaches (Anoda cristata (L.) Schltdl.) and quelite de agua Amarantus retroflexus L.)], bonnets (Jacaratia mexicana A. DC.), and hog-plums (Spondias purpurea L.). The domesticated plants have a greater fitness under cultivation and are propagated from vegetative parts, seeds, and/or transplants of complete individuals. Among the Mexican domesticates are maize (Zea mays L.), pumpkins (Cucurbita pepo L.), and beans (Phaseolus vulgaris L.) [2-7]. In other cases of domesticated plants such as prickly-pear cactus (Opuntia ficus-indica (L.) Mill.), guajes (Leucaena spp.), and agaves (Agave spp.) [8-10], inter-specific hybridization is an important mechanism of domestication and is currently of great interest [11]. The common suite of differential characteristics between cultivated domesticates and their ancestors (wild, tolerated, encouraged, or parental in the case of hybridization) is known as domestication syndrome, which includes gigantism in used parts and correlated structures, indicating its evolutionary process under domestication $[1,12]$.

Little is known about the domestication of medicinal plants in Mexico where between 3000 and 5000 native and introduced species are used by more than 69 indigenous peoples of the country. The main botanical families used in Mexican traditional medicine (MTM, hereafter) are Asteraceae, Lamiaceae, Solanaceae, in which many of their species are aromatic [13, 14].

Ethnopharmacological studies among the Popoluca (Veracruz), Mixe (Oaxaca), and Maya (Chiapas and Yucatán) indicate that aromatic organoleptic properties are a determinant for the consumption of plants for medicinal purposes ([15-19], respectively). These studies along with Geck et al. (2017a,b) confirm that odor and taste of plants are immersed in the culture, resulting in various organoleptic categories such as sweet, bitter, spicy, sour, fetid, among others $[20,21]$. These characteristics are considered the main criteria in determining the appropriate treatment to alleviate given ailments. For example, among the Mixe people, sweet aromatic plants are preferred in the treatment of gastrointestinal ailments [16].

In addition, the plant's morphology influences its preference for medicinal use. In the case of epazote (Dysphania ambrosioides (L.) Mosyakin and Clemants), leaf color, size, and shape, in addition to the organoleptic characteristics, are selection criteria of mestizo inhabitants with Mazatec ancestry of Santa María Tecomavaca, Oaxaca, to differentiate their employment of different forms as a condiment or an antiparasitic medication [22].

Genetic, environmental, and ecological variables, as well as the stage of plant's development (seedling, plantlet, flowering or fruiting, etc.), influence their organoleptic characteristics, which are directly related to the chemical composition of their essential oil [23, 24]. Similarly, these variables contribute to the wide phenotypic variation within and between populations [24]. These variations in the domestication complex due to genetic selection need to be distinguished from the consequences of phenotypic plasticity in response to environmental variables [25]. It is important to demonstrate that management and selection lead to a morphophysiological and organoleptic differentiation based upon genetic and phytochemical divergence between cultivated populations and their wild ancestors (the progenitor species or, in case of hybridization, the parental species). Several studies have suggested that the design of a common garden with homogeneous conditions reduces environmental variability. Thus, the expression of 
genetically based morphological and phytochemical differentiation between wild and cultivated populations allows one to identify selection criteria that humans have exerted on them $[22,26]$.

A good model to generate knowledge about the domestication process in aromatic medicinal plants of Mexico is Mexican hyssop belonging to the genus Agastache section Brittonastrum (Lamiaceae; Mentheae). Both Agastache mexicana (Kunth) Lint and Epling and Agastache mexicana subsp. xolocotziana Bye, Linares \& Ramamoorthy are known in the MTM as "toronjil morado" and "toronjil blanco," respectively, and are used together in infusions for their calming effect [27]. A. mexicana grows spontaneously and under cultivation throughout the Neovolcanense Province of central Mexico, especially in region of the Popocatepetl volcano, in the Ozumba Municipality, State of Mexico (Edomex), and in the Milpa Alta County, Mexico City (CDMX) [28, 29].

The subsp. xolocotziana only occurs in a cultivated state in central Mexico (CDMX, Edomex and Morelos). The absence of wild populations with white flowers, sterile pollen, and fruits, and vegetative reproduction via rhizomes, suggest that this taxon may be a product of hybridization [27]. Given the proximity of allopatric populations and the capacity of humans to breach the geographical barrier with $A$. mexicana (pine-oak forest, between 2800 and $3200 \mathrm{~m}$ asl), Agastache palmeri (B.L. Rob.) Standl. (of southern Sierra Madre Orientalense, especially in pine forest of Hidalgo and Puebla, between 2900 and $3200 \mathrm{~m}$ asl) was proposed as the other putative parental species $[27,30]$.

The basis of this hypothesis is that this subspecies has (a) morphologically intermediate phenotype, a single report of a morphologically intermediate, sterile hybrid between A. mexicana and A. palmeri [30]; (b) reduction in sexual reproduction, low viability in pollen (30\%) compared to A. mexicana and A. palmeri ( $80 \%$ in both cases) [30; personal communication R. Bye]; (c) asexual reproduction, its propagation is vegetative through rhizomes [27]; and (d) novel characters such as the presence of approximately three times more compounds in the essential oil of the subsp. xolocotziana (38 compounds) compared to those found in A. mexicana (11 compounds) [31].

Documenting domestication processes in aromatic medicinal plants elucidates their evolutionary dynamics and compares its syndrome with other groups of plants used for other purposes. Hence, we can also lay the groundwork for understanding the domestication process in this complex and diverse group, little studied from this perspective [25]. This information is also the basis for implementing conservation and management strategies for these fundamental therapeutic resources in the MTM [32].
The objectives of this report are (1) to provide ethnobotanical, morpho-physiological, and phytochemical evidence for the understanding of the domestication processes of $A$. mexicana, by comparing different populations found along the domestication gradient, and the subsp. xolocotziana contrasting it with the putative parents, and (2) to generate information about the possible hybrid origin of latter taxon. We expected (1) the existence of organoleptic, morpho-physiological, and phytochemical dissimilarities between the populations involved in the domestication gradient of $A$. mexicana and in the populations of $A . m$. subsp. xolocotziana with respect to their putative parents, and (2) a pattern of differentiation of characteristics that coincide with hybridization as a possible origin of subsp. xolocotziana.

\section{Materials and method Studied species}

Agastache mexicana (purple Mexican hyssop) and its subsp. xolocotziana (white Mexican hyssop) are aromatic herbs important in MTM. They are known and used beyond their natural geographic range, grown under cultivation, and commercialized internationally [13, 27]. Ethnobotanical, taxonomic, and phytochemical studies support their taxonomic relationship. The typical $A$. mexicana has an anis odor, purple corolla, triangular leaves with serrate margin in the lower blade, and essential oils with 11 compounds (the most abundant being estragole and limonene). Its subsp. xolocotziana has a mentholated odor, white corolla with trichomes on its lower lip, lanceolate leaves and crenate margin, and essential oils with 38 compounds (the most abundant being pulegone and limonene) [27, 31, 33].

The first written mention of $A$. mexicana occurred in the sixteenth century (1552) when it was registered in Libellus de medicinalibus indorum herbis, one of the oldest manuscripts of Mexican medicinal plants (also known as Codex de la Cruz-Badiano), under the Nahuatl name of tlalahuehuetl; its sap was applied to wounds [34-36]. A decade later, Francisco Hernández, the physician of the Spanish King Philip II, recorded tlalahoehoetl in the treatment of gastrointestinal ailments, urinary problems, and ophthalmological disorders in central Mexico [27, 37]. On the other hand, the use of the subsp. xolocotziana was not recorded until the twentieth century (1939) in Las Plantas Medicinales de México, being reported to treat gastrointestinal ailments and as an anti-spasmodic [38]. Currently, both aromatic herbs combined together in an infusion are drunk for treating gastrointestinal, cardiovascular, menstrual, and nerve pains; the "toronjiles" are also used to combat insomnia, as a sedative, and in the treatment of culturally affiliated ailments such as "susto" or "espanto" [27, 39, 40]. 
Recent phytochemical and pharmacological studies report the analgesic and anti-inflammatory effect of the organic extract of both taxa [40-42]. Similar extracts of $A$. mexicana relax bronchial smooth muscles of the guinea pig (Cavia sp.) [43] while those of subsp. xolocotziana induce contractions [44]. Anticonvulsant effect of the extracts of both taxa along with Dracocephalum moldavica L., an introduced Lamiaceae known as "toronjil azul" (blue hyssop), has been documented [45]. These three toronjiles (purple, white, and blue) form part of the "ethnobotanical medicinal complex toronjil" [46].

\section{Study area}

Based upon bibliographic searches, survey of specimens in the National Herbarium (MEXU-Herbario Nacional de México), and visits to markets in central Mexico, the following taxa and their management regime were detected: A. mexicana-cultivated and encouraged, A. mexicana subsp. xolocotziana-cultivated, and A. palmeri-tolerated. Three field study sites were selected (Fig. 1, Table 1):

1. Santiago Mamalhuazuca, Ozumba, Edomex. The municipality of Ozumba, located in the foothills of the western part of the Popocatepetl volcano (between 1800 and 2600 m asl; temperature ranges between 12 and $20^{\circ} \mathrm{C}$; precipitation between 800 and $1000 \mathrm{~mm}$ ). The population is 27,207 inhabitants, the majority mestizos conserving a small Nahuatl indigenous sector (1.1\%) [47, 48]. Cultivation and marketing of medicinal plants are major economic activities in this village. The principal species include $A$. mexicana, Heterotheca inuloides Cass., Tagetes lucida Cav., and Justicia spicigera Schltdl [29].. At this site, cultivated populations of both A. mexicana and the subsp. xolocotziana are found.

2. San Pablo Oztotepec, Milpa Alta, CDMX. Milpa Alta county is located in southern CDMX (average elevation $2420 \mathrm{~m}$ asl.), with a population of 130,582 persons, including the largest Nahuatl population in Mexico City [47]. The harvesting of medicinal plants, including A. mexicana, supplies the central medicinal plant market (Mercado Sonora) in downtown Mexico City [28]. In this locality, only encouraged populations of $A$. mexicana were found.

3. Puerto de Piedra, Nicolás Flores, Hidalgo. The municipality Nicolás Flores is located in the state of Hidalgo

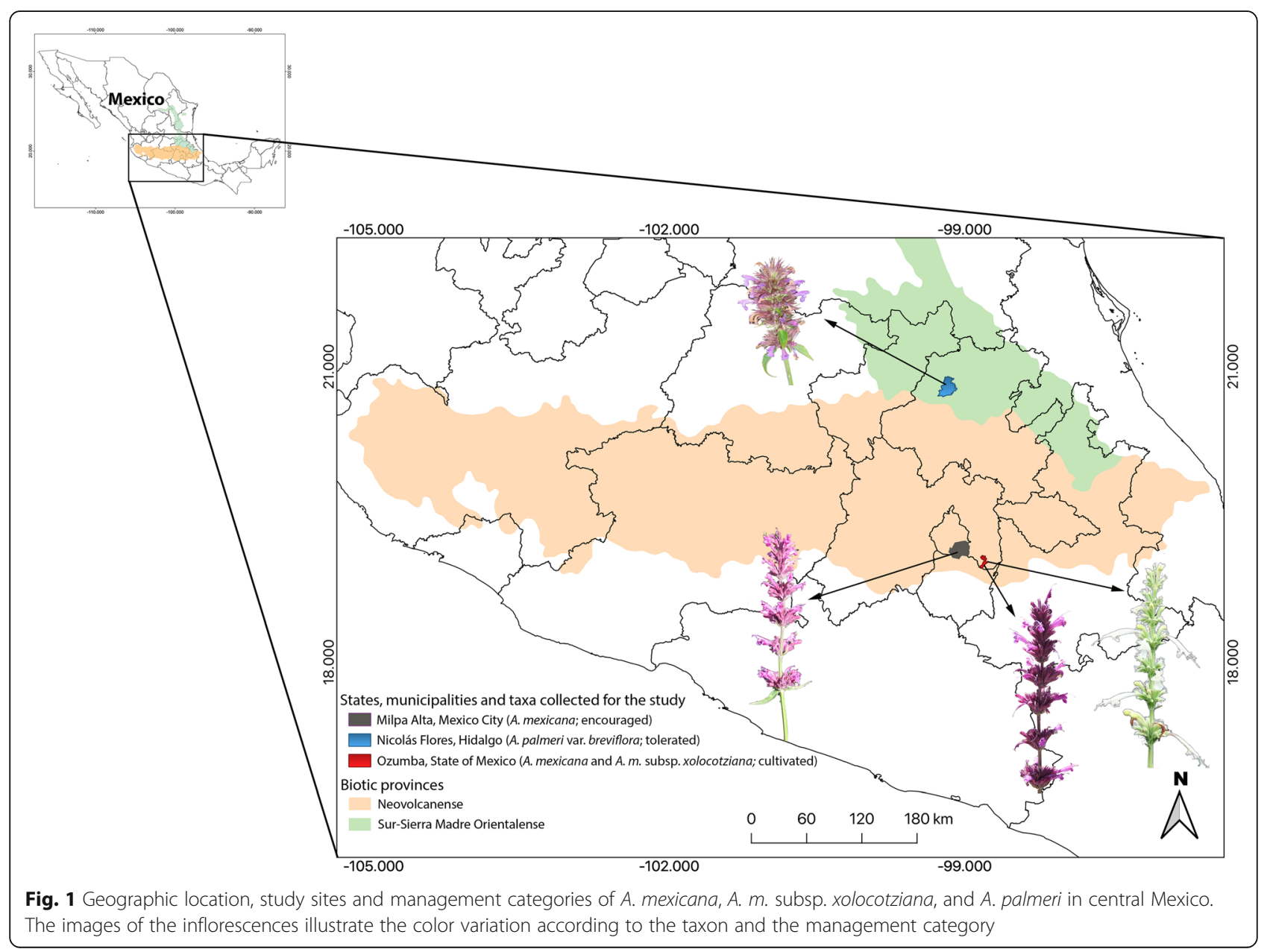


Table 1 Taxa, management category, number of populations, number of individuals per population, total individuals, and sites considered in the morphological variation analysis. Initially, ten individuals were included in each population, however some did not survive

\begin{tabular}{llllll}
\hline Taxa & Category & No. of populations & No. of ind. per population & Total no. of ind. & Locality \\
\hline A. mexicana & Encouraged & 4 & $9,7,7,6$ & 29 & San Pablo Oztotepec, Milpa Alta, CDMX \\
& Cultivated & 3 & $9,8,7$ & 24 & Santiago Mamalhuazuca, Ozumba, Edomex \\
A.m.subsp. xolocotziana & Cultivated & 3 & $8,7,7$ & 22 & Santiago Mamalhuazuca, Ozumba, Edomex \\
A. palmeri & Tolerated & 3 & $8,7,7$ & 22 & Puerto de Piedra, Nicolás Flores, Hgo. \\
\hline
\end{tabular}

in the Sierra Madre Oriental mountain range, with 7031 inhabitants, where approximately half speak an indigenous language, mainly Otomi [47]. The vegetation is mainly pine-oak forests (elevations from 900 to $2800 \mathrm{~m}$ asl; precipitation from 800 to $1100 \mathrm{~mm}$; temperature between 12 and $22{ }^{\circ} \mathrm{C}$ ); part of this territory belongs to the Los Mármoles National Park. Also at this locality, tolerated populations of $A$. palmeri var. breviflora R.W. Sanders were managed.

\section{Ethnobotanical evidence}

In the first two study sites, Ozumba, Edomex, and Milpa Alta, CDMX, visits were made every 2 months over a 2year period. A total of 80 semi-structured interviews were conducted (40 at each site), in addition to botanical walks, participant observation and collection of plant material (seeds and complete plants) to document traditional knowledge, uses, and selection criteria (organoleptic and morpho-physiological characteristics) according to their use and management [16, 22, 49, 50]. The selection of the people for interviews was carried out by means of a "snowball" sampling [51]. The analysis of ethnobotanical data was carried out through summary statistics. In the third site, Nicolás Flores, Hidalgo, only seeds and complete plants of $A$. palmeri collected to document the two categories of evidence described below.

\section{Morpho-physiological evidence (under standardized conditions)}

A common garden experiment was established within a greenhouse located in the Botanical Garden of the Institute of Biology (Instituto de Biología) of the National Autonomous University of Mexico (Universidad Nacional Autónoma de México) in Mexico City. Twenty-one morpho-physiological characters (vegetative, inflorescence, flowers, and seeds) were evaluated. These characters were based upon criteria for the use and management of these plants derived from the ethnobotanical inquiries (shown in Table 2, in addition to germination percentage). Because the harvest of the "toronjil" occurs when it blooms, data collection was carried out at the floral stage.

Through a completely randomized design, four treatments were established consisting of three factors: (a) taxon, (b) degree of management, and (c) population. The treatments consisted of (1) A. mexicana + encouraged + Milpa Alta; (2) A. mexicana + cultivated + Ozumba, (3) A. $m$. subsp. xolocotziana + cultivated + Ozumba, and (4) A. palmeri + tolerated + Nicolás Flores. For each treatment, seeds were collected from three different populations in each location, except the first, where four populations were collected. The analysis of the morphological variation was obtained from a total of 13 populations and 97 individuals (Table 1). From each field population, voucher specimens were collected and deposited in the National Herbarium (MEXU).

Table 2 Characters evaluated in the analysis of principal components and eigenvectors of the first and second principal components

\begin{tabular}{|c|c|c|c|}
\hline Character & Units & PC1 & PC2 \\
\hline Total height & $\mathrm{cm}$ & -0.24450137 & -0.25309168 \\
\hline Leaf area & $\mathrm{cm}^{2}$ & -0.20287308 & -0.19621089 \\
\hline Leaf color & pxs & 0.10959718 & 0.012094649 \\
\hline Number of leaves & quantity & -0.14272378 & -0.005930697 \\
\hline Number of teeth & quantity & -0.25294183 & -0.084785244 \\
\hline Number of stem nodes & quantity & -0.12264778 & -0.457384999 \\
\hline Inflorescence Length & $\mathrm{cm}$ & -0.14389938 & -0.233460479 \\
\hline $\begin{array}{l}\text { Number of inflorescence } \\
\text { nodes }\end{array}$ & quantity & 0.21010157 & -0.114973125 \\
\hline Number of flowers produced & quantity & -0.2518971 & -0.128068981 \\
\hline Style length & $\mathrm{cm}$ & 0.31203141 & -0.20260069 \\
\hline Length of lower stamens & $\mathrm{cm}$ & 0.31459679 & -0.225227546 \\
\hline Length of upper stamens & $\mathrm{cm}$ & 0.31311366 & -0.224199747 \\
\hline Flower tube length & $\mathrm{cm}$ & 0.28171594 & -0.293324118 \\
\hline Flower length & $\mathrm{cm}$ & 0.31435775 & -0.223206556 \\
\hline Corolla color & pxs & 0.11529446 & 0.36229973 \\
\hline Rhizome length & $\mathrm{cm}$ & 0.11838912 & 0.325060595 \\
\hline Rhizome diameter & $\mathrm{cm}$ & 0.01026666 & 0.043661684 \\
\hline Number of rhizome nodes & quantity & 0.21010157 & 0.23809349 \\
\hline Seed length & $\mathrm{cm}$ & 0.27176266 & -0.138544241 \\
\hline Seed diameter & $\mathrm{cm}$ & 0.16784207 & -0.064307995 \\
\hline
\end{tabular}

Bold values indicate the dominant characters in each component 
Statistical analysis of morpho-physiological characters All analyses were performed with the Software $\mathrm{R}$ ver. 1.0.153 [52]. In order to document the pattern of grouping and discontinuities in the total variation, two analyses were made: (1) cluster analysis and (2) principal component analysis (PCA). For the first analysis, a matrix of population means was used, whose elements were standardized to mean $=0$ and variance $=1$; subsequently, a distance matrix was obtained using the square of the Euclidean distance. Cluster analysis was performed using the average distance method (unweighted pair group method using arithmetic mean-UPGMA) and represented by a dendrogram using a standardized average distance as weight. The total populations and characters were considered in this analysis.

The PCA was performed to analyze the relationship between the taxa under study and estimate the importance of the characters that discriminate among them. This analysis was carried out using a matrix that included 97 individuals and 20 morpho-physiological variables (the germination percentage variable was not considered for this analysis because it was obtained on the basis of populations rather than on individuals). Similarly, the elements of the matrix were standardized to mean $=0$ and variance $=1$. Subsequently, the matrix of correlations between the variables was generated, which served as the basis for calculating the characteristic values and vectors; next, the study units (individuals) were projected on the axes that represent the first two principal components.

In order to document significant differences between management categories and domestication trends in the 21 characters evaluated, we framed our analyses upon two questions. First, what are the differences between the encouraged and cultivated populations of $A$. mexicana? For this, Student's $T$ test was carried out considering a total of 53 individuals of $A$. mexicana (encouraged (29) and cultivated (24)). Second, what are the differences between the subsp. xolocotziana and its putative parents? For this question, an ANOVA was carried out considering a total of 73 individuals (subsp. xolocotziana (22), A. mexicana encouraged (29), and A. palmeri (22)).

In all cases, normality and homogeneity, Shapiro-Wilk and Levene, respectively, were determined prior to the analyses. Tukey's post hoc test was used when necessary. When the variables did not meet the assumptions of normality and homogeneity, a Kruskal-Wallis test was used.

\section{Phytochemical evidence Essential oil extraction}

Once the morpho-physiological evaluation of the plants was completed, the essential oil was extracted from the aerial parts of the plants (stem, leaves, and inflorescence) for each population using hydrodistillation. Fifteen grams of pulverized plant material were extracted in 250 $\mathrm{ml}$ of distilled water to attain a final volume of $90 \mathrm{ml}$ of an emulsion of essential oil and water. The essential oil was obtained by partition with ethyl acetate (1:1). The organic phase was recovered and concentrated under reduced pressure at a maximum temperature of $40{ }^{\circ} \mathrm{C}$ resulting in a final volume of $2 \mathrm{ml}$. The essential oil was stored in amber vials and kept refrigerated $\left(4{ }^{\circ} \mathrm{C}\right)$ for further chemical profile analysis.

\section{Thin layer chromatography}

The chemical profile of the essential oil from each population was obtained by means of a thin layer chromatography (TLC); five main aromatic compounds were reported for "toronjil" ethnobotanical complex: estragole, geraniol, linalool, menthone, and pulegone [40, 53]. The analytical conditions of the TLC were the following: the stationary phase consists in silica gel chromatoplates (TLC silica gel $60 \mathrm{~F}_{254}$; Merck), the mobile phase was toluene-ethyl acetate (95:5), UV light (254 and $360 \mathrm{~nm}$ ), and anisaldehyde reagent derivatization [54]. For each compound analyzed, the retention factor $\left(R_{\mathrm{f}}\right)$ was calculated. Subsequently, the absence or presence of the five standards mentioned for each population was scored. The comparison was made by management categories.

\section{Results \\ Ethnobotanical evidence \\ Use}

The $80 \%$ of the people interviewed mention that the infusion combining A. mexicana and the subsp. xolocotziana is drunk to treat principally (75\%) gastrointestinal, menstrual, and nerve pains as well as to combat "coraje" (an intense anger or disgust said to be an emotion expressed by great irritability) and secondarily (60\%) in cases of "susto" or "espanto" (an ailment of cultural affiliation generated from an impression or deep fear, whose physical characteristics are: sunken eyes and yellow irises, paleness, loss of hunger, exhaustion, insomnia or drowsiness, and anxiety) [39]. Along with drinking the infusion, one is bathed nightly in a tub of hot water containing the "toronjiles," until one is relaxed. In third place $(40 \%)$, A. mexicana in form of poultices and infusions is recommended to alleviate pain generated by contusions. For treating these ailments, the people preferred using A. mexicana and the subsp. xolocotziana instead of árnica (Heterotheca inuloides Cass.) which is similarly employed.

\section{Traditional knowledge and selection criteria}

Eighty percent of the people interviewed recognized two categories of A. mexicana: "toronjil morado de monte" (purple wild hyssop) and "toronjil morado de casa" 
(purple house hyssop) referring to the encouraged and cultivated populations, respectively. They differentiated the two based mainly on organoleptic (60\%), floral (30\%), and vegetative $(10 \%)$ characteristics. The purple wild hyssop has a smell and taste of hyssop, that is, with a menthol aroma and with pale purple flowers, while the purple house hyssop has a strongly aniseed, sweet taste, and smell, with a more intense color of the leaves and flowers more intense than that of the wild one. The purple house hyssop is preferred over the wild to treat the ailments described above having greater consumption and effectiveness when the plants are in the floral stage.

Hundred percent of the informants referred to the subsp. xolocotziana as "toronjil blanco de casa" (white house hyssop) and mentions that this plant does not occur in the wild. They differentiate it from other hyssops mainly for their floral (70\%), organoleptic (60\%), and vegetative $(30 \%)$ characteristics. They distinguish it by its flavor and smell of menthol, white flowers, olivegreen leaves, and a stout rhizome.

The $80 \%$ of the people interviewed mentioned that purple and white house hyssops are highly valued for their medicinal effectiveness when consumed together as an infusion, having greater effectiveness when plants are in the floral stage and consumed in fresh. However, 50\% also use them in the form of vegetative shoot or as shade-dried plants.

\section{Management}

\section{Encouraged populations of A. mexicana}

All the people interviewed in San Pablo Oztotepec recognized that plants of purple wild hyssop tend to grow in disturbed habitats near "milpas," traditional agricultural fields. The plants are valued for their medicinal and ornamental use and increase in density in response to weeding so as to remove other plants compete with them. At the time of harvesting these plants, people only cut the aerial part, leaving the rhizome so that it can produce new shoots during the next growing season. Another practice is that not all plants are harvested at the flowering time, thus leaving some inflorescences to produce seeds that subsequently fall to the ground and germinate.

\section{Cultivated populations of A. mexicana and A. m. subsp. xolocotziana}

Agastache mexicana and its subsp. xolocotziana (purple and white house hyssop, respectively) are widely cultivated in the town of Santiago Mamalhuazuca. Propagation is mainly done through the rhizome. However, 30\% of the informants mention that they produce seedlings to introduce plants that are hardier and more resistant to environmental variations. However, in the case of white house hyssop, they mention that "few seeds germinate" and of those, they select the most vigorous plants to transplant although not all survive.

The interviewees of Santiago Mamalhuazuca mentioned that the white house hyssop is "chiquión" (that it does not withstand extreme changes in temperature and humidity) while the purple house hyssop is more resistant. The inhabitants of this town also cultivate other medicinal plants in their fields, such as fennel (Foeniculum vulgare Mill.), borage (Borago officinalis L.), rue (Ruta chalepensis L.), gordolobo (Gnaphalium spp.), pericón (Tagetes lucida), and epazote (Dysphania graveolens), that are grown in mosaic. Each year, they alternate the crops so as to favor the vigorous plants. The cultivation of purple and white hyssops begins in April so as to harvest the aerial part of the plants (stem and inflorescence) in November. The rhizome sprouts stems, thus allowing another harvest in the next month of February. The first harvest produces a greater quantity of plants than the second one, resulting in a higher sale price in February.

In Santiago Mamalhuazuca, the purple and white house hyssops are grown in greater quantity than other medicinal plants, such as pericón, rue, etc. The major sale of bundles and consumption (in mixture) occur when the plants are in the floral stage.

In the mixed bundles, the greater portion consists of the house purple hyssop rather than white hyssop. The people explain that the latter "gives less," that is that the plants are smaller and produced in lesser quantities, especially when drastic climatic changes occur during the growing season. Based upon response to inquiries about provenance of cultivated germplasm (that is inherited among parents, siblings, and extended families), it is estimated that they have been cultivating the two Mexican hyssops for approximately 100 years.

\section{Morpho-physiological evidence \\ Discontinuities in the pattern of total variation and the clustering pattern}

The evaluation of the 21 morphological characters in the 13 populations that include a total of 97 individuals reflects, in the UPGMA cluster analysis (Fig. 2), three groups: in the first group (I) are the three populations of A. palmeri, in the second (II) the three of the subsp. xolocotziana, while in the third (III) are the seven studied populations of $A$. mexicana. In this last group, two subgroups are observed, one that includes the four encouraged populations (V) and the other (IV) with the three cultivated.

The dispersion of the individuals in the PCA chart (Fig. 3) supports the grouping of the previous analysis. In the upper left quadrant of Fig. 3 are the individuals of $A$. palmeri. In the lower center are the individuals of $A$. mexicana (where the cultivated plants of this taxon tend to separate from those 


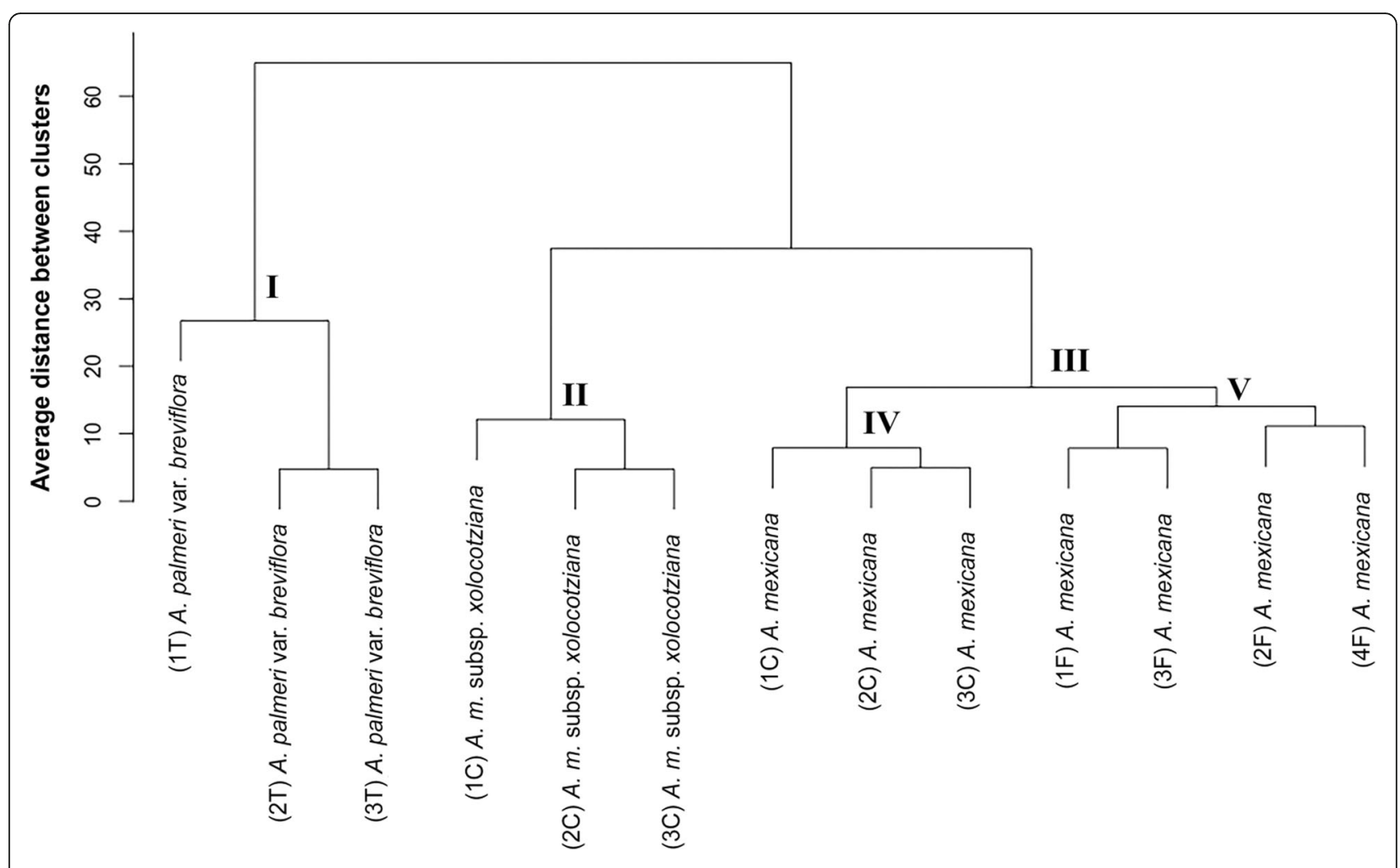

Fig. 2 UPGMA dendrogram of the evaluated populations of A. mexicana and A. palmeri. F encouraged, C cultivated, and T tolerated

encouraged population). Finally, the subsp. xolocotziana is segregated in the upper right quadrant. The first two components explain 43.01 and $13.95 \%$, respectively, of the total variance of the individuals evaluated.
Considering the characters with greater weight in the first component, the cultivated plants of both $A$. mexicana and the subsp. xolocotziana have larger size (length) in structures related to flowers (style (0.312), upper and lower stamens $(0.314$ and 0.313 ,

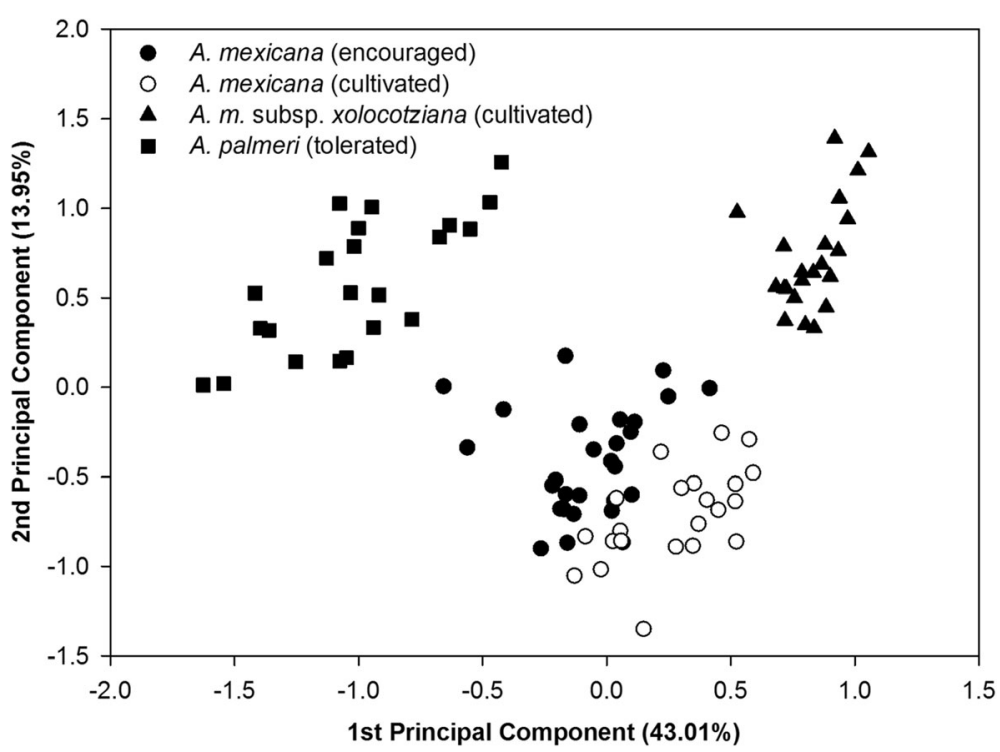

Fig. 3 Graph of the first and second principal component derived from the evaluation of 20 morphological characters in the 97 individuals evaluated. Table 2 shows the vectors with the highest weight in each component 
respectively), tube (0.281), and flower (0.314)), and greater seed length. In addition, the subsp. xolocotziana displays a smaller number of teeth in the margin of the leaf $(-0.252)$, a smaller number of flowers $(-0.251)$, and smaller plants $(-0.244)$ when compared with the $A$. mexicana and encouraged plants tolerated from A. palmeri.

The characters with greater weight in the second component show that the subsp. xolocotziana have a smaller number of nodes in the stem $(-0.457)$, differentiation in the color of the flower (0.362/white flowers), and a greater length in the rhizome (0.325) when compared to A. mexicana and A. palmeri (Fig. 3, Table 2).

\section{Significant differences and trends in domestication of $A$.} mexicana (encouraged and cultivated plants)

When comparing the encouraged and cultivated plants of $A$. mexicana, significant differences $(P<0.05)$ were found in 12 of the 20 characters evaluated. Table 3 shows the trends of domestication of A. mexicana.
Five of these characters are related to reproductive structures. In cultivated plants, these characters suggest being related to gigantism in flowers and their greater pigmentation in them. With respect to the seeds, those of the cultivated form are larger than those of the encouraged form. These characteristics are very important in anthropocentric terms. Contrary to expectations, the cultivated Mexican hyssop has shorter inflorescences than the encouraged form.

Likewise, there are significant differences in two of three vegetative characters. The cultivated plants have larger leaves and a greater number of nodes in the rhizome than those of the encouraged plants. The differentiation in the leaves is related to a gigantism in the parts used. The difference in the rhizome suggests selection favoring greater asexual reproduction. However, total plant height of the cultivated Mexican hyssop is lower than that of the encouraged form.

Table 3 Averages and standard error of 12 characters that presented significant differences when comparing categories 1 (= encouraged) and 2 (= cultivated) in A. mexicana. Domestication trends that indicate these characters are presented

\begin{tabular}{|c|c|c|c|c|c|c|}
\hline Characters & & Domestication trend & Category & Mean/SE & Student $T$ & $P$ \\
\hline \multirow[t]{14}{*}{ Floral } & \multirow[t]{2}{*}{ Corolla color } & \multirow[t]{2}{*}{ More pigmented flowers } & 1 & $133.3 \pm 1.72$ & \multirow[t]{2}{*}{4.28} & \multirow[t]{2}{*}{$0.000^{*}$} \\
\hline & & & 2 & $120.1 \pm 2.66$ & & \\
\hline & \multirow[t]{2}{*}{ Inflorescence length } & \multirow[t]{2}{*}{-} & 1 & $19.73 \pm 1.91$ & \multirow[t]{2}{*}{3.02} & \multirow[t]{2}{*}{$0.003^{* *}$} \\
\hline & & & 2 & $12.15 \pm 1.48$ & & \\
\hline & \multirow[t]{2}{*}{ Style length } & \multirow[t]{2}{*}{ Longest style, gigantism } & 1 & $3.49 \pm 0.05$ & \multirow[t]{2}{*}{3.58} & \multirow[t]{2}{*}{$0.000^{*}$} \\
\hline & & & 2 & $3.74 \pm 0.03$ & & \\
\hline & \multirow[t]{2}{*}{ Length of lower stamens } & \multirow[t]{4}{*}{ Longer stamens, gigantism } & 1 & $2.74 \pm 0.05$ & \multirow[t]{2}{*}{5.57} & \multirow[t]{2}{*}{$0.000^{*}$} \\
\hline & & & 2 & $3.13 \pm 0.03$ & & \\
\hline & \multirow[t]{2}{*}{ Length of upper stamens } & & 1 & $3.08 \pm 0.06$ & \multirow[t]{2}{*}{5.06} & \multirow[t]{2}{*}{$0.000^{*}$} \\
\hline & & & 2 & $3.47 \pm 0.04$ & & \\
\hline & \multirow[t]{2}{*}{ Flower tube length } & \multirow[t]{2}{*}{ Longest flower tube, gigantism } & 1 & $2.24 \pm 0.04$ & \multirow[t]{2}{*}{5.47} & \multirow[t]{2}{*}{$0.000^{*}$} \\
\hline & & & 2 & $2.59 \pm 0.03$ & & \\
\hline & \multirow[t]{2}{*}{ Flower length } & \multirow[t]{2}{*}{ Larger flowers, gigantism } & 1 & $2.74 \pm 0.05$ & \multirow[t]{2}{*}{7.61} & \multirow[t]{2}{*}{$0.000^{*}$} \\
\hline & & & 2 & $3.21 \pm 0.02$ & & \\
\hline \multirow[t]{4}{*}{ Seeds } & \multirow[t]{2}{*}{ Seed length } & \multirow[t]{4}{*}{ Longer and wider seeds, gigantism } & 1 & $1.8 \pm 0.02$ & \multirow[t]{2}{*}{5.76} & \multirow[t]{2}{*}{$0.000^{*}$} \\
\hline & & & 2 & $2.04 \pm 0.03$ & & \\
\hline & Seed diameter & & 1 & $0.87 \pm 0.02$ & 4.09 & $0.000^{*}$ \\
\hline & & & 2 & $1.02 \pm 0.02$ & & \\
\hline Vegetative & Total height & - & 1 & $98.83 \pm 3.59$ & 1.63 & $0.000^{*}$ \\
\hline & & & 2 & $90.53 \pm 3.48$ & & \\
\hline & Leaf area & Larger leaves, gigantism & 1 & $7.74 \pm 0.29$ & 2.47 & $0.016^{* * *}$ \\
\hline & & & 2 & $8.92 \pm 0.38$ & & \\
\hline & Number of rhizome nodes & More nodes in the rhizome, & 1 & $1.86 \pm 0.12$ & 2.69 & $0.009^{* *}$ \\
\hline & & greater asexual reproductive capacity & 2 & $2.5 \pm 0.20$ & & \\
\hline
\end{tabular}

\footnotetext{
* Significant level $0.001,{ }^{* *}$ significant level 0.01 and ${ }^{* * *}$ significant level 0.05
} 
Table 4 Means and standard error of 19 characters that presented significant differences when comparing the plants of (1) A. $m$. subsp. xolocotziana with (2) A. mexicana (encouraged) and (3) A. palmeri. Domestication trends of the subsp. xolocotziana are shown

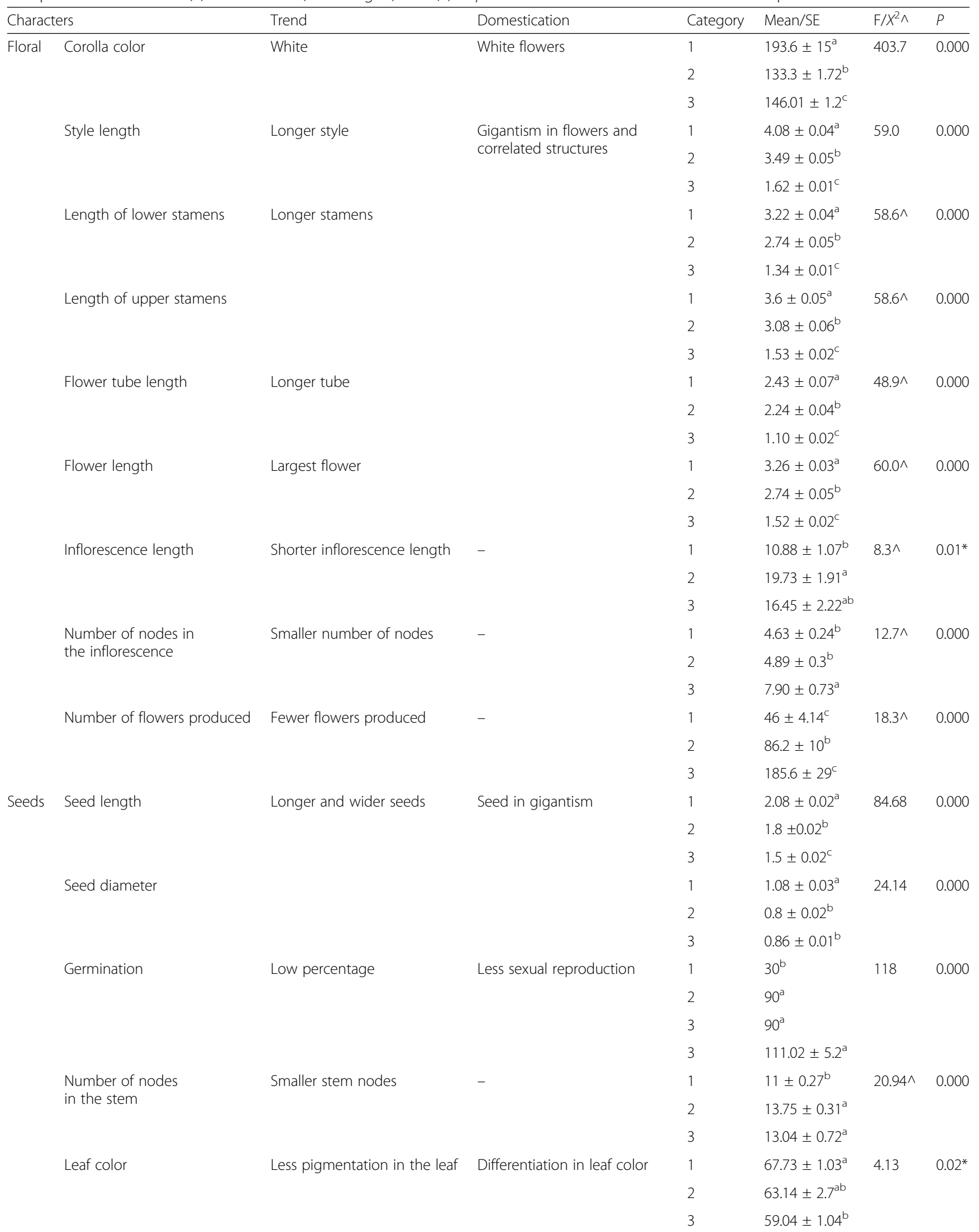


Table 4 Means and standard error of 19 characters that presented significant differences when comparing the plants of (1) A. $m$. subsp. xolocotziana with (2) A. mexicana (encouraged) and (3) A. palmeri. Domestication trends of the subsp. xolocotziana are shown (Continued)

\begin{tabular}{|c|c|c|c|c|c|c|}
\hline Characters & Trend & Domestication & Category & Mean/SE & $F / X^{2} \wedge$ & $P$ \\
\hline \multirow[t]{3}{*}{ Leaf area } & \multirow[t]{3}{*}{ Smaller leaf area } & \multirow[t]{3}{*}{-} & 1 & $6.59 \pm 0.32^{\mathrm{a}}$ & \multirow[t]{3}{*}{21.35} & \multirow[t]{3}{*}{0.000} \\
\hline & & & 2 & $7.74 \pm 0.29^{a}$ & & \\
\hline & & & 3 & $10.03 \pm 0.47^{b}$ & & \\
\hline \multirow{3}{*}{$\begin{array}{l}\text { Number of teeth } \\
\text { on the leaf }\end{array}$} & \multirow[t]{3}{*}{ Less teeth } & \multirow[t]{3}{*}{-} & 1 & $11 \pm 0.27^{b}$ & \multirow[t]{3}{*}{35.54} & \multirow[t]{3}{*}{0.000} \\
\hline & & & 2 & $13.63 \pm 0.38^{\mathrm{a}}$ & & \\
\hline & & & 3 & $16.17 \pm 0.53^{\mathrm{a}}$ & & \\
\hline Rhizome Length & \multirow{6}{*}{$\begin{array}{l}\text { Longest rhizome with } \\
\text { greater number of nodes }\end{array}$} & \multirow{6}{*}{$\begin{array}{l}\text { Gigantism in rhizome, greater } \\
\text { asexual reproductive capacity }\end{array}$} & 1 & $3.96 \pm 0.28^{\mathrm{a}}$ & \multirow[t]{3}{*}{32.54} & \multirow[t]{3}{*}{0.000} \\
\hline \multirow{5}{*}{$\begin{array}{l}\text { Number of rhizome } \\
\text { nodes }\end{array}$} & & & 2 & $2.08 \pm 0.23^{b}$ & & \\
\hline & & & 3 & $2.3 \pm 0.21^{b}$ & & \\
\hline & & & 1 & $4.72 \pm 0.26^{\mathrm{a}}$ & \multirow[t]{3}{*}{79.16} & \multirow[t]{3}{*}{0.000} \\
\hline & & & 2 & $2.51 \pm 0.20^{b}$ & & \\
\hline & & & 3 & $1.72 \pm 0.16^{c}$ & & \\
\hline
\end{tabular}

Different letters indicate significant differences. Significant level $0.001,{ }^{*}$ significant level 0.05

Significant differences and trends in domestication in A. $m$. subsp. xolocotziana

When comparing the subsp. xolocotziana with its putative parents, A. mexicana (encouraged) and A. palmeri, 19 characters were found that differ significantly from the 21 characters evaluated in the study (Table 4).

All the reproductive characters evaluated had significant differences. They indicate that the subsp. xolocotziana has white flowers (in contrast to the pigmented flowers), and larger corolla, although fewer flowers per inflorescence. Flower size is a humanselected feature. The seeds of subsp. xolocotziana are larger; however, they have a low germination percentage. The seed gigantism may be a pleiotropic effect that is related to flower size.

Seven vegetative characters differed significantly. The plants of the subsp. xolocotziana are shorter, with smaller leaves and fewer teeth in comparisons to $A$. mexicana and $A$. palmeri. Very significant differences are found in the rhizome. The longer rhizome with more nodes affords greater asexual reproductive capacity. This feature is directly related to its management mainly through vegetative propagation.

\section{Phytochemical evidence}

Comparison of the chemical profiles of essential oils between the encouraged and cultivated plants of $A$. mexicana (Table 5) reveals that the former only present geraniol and pulegone, while the cultivated ones contain the five compounds evaluated: estragole, linalool, menthone plus the two cited above. All five compounds are present in the subsp. xolocotziana plants. In the case of A. palmeri, only three of them (geraniol, menthone, and pulegone) are registered (Table 5).

\section{Discussion}

\section{Domestication of Agastache}

This study presents ethnobotanical, morphophysiological, and phytochemical evidence about the domestication processes of $A$. mexicana and $A . m$. subsp. xolocotziana. On the one hand, this information shows a differentiation between the encouraged and cultivated populations of $A$. mexicana along the domestication gradient. On the other hand, subsp. xolocotziana diverged from one of its putative parents of hybridization (Table 6).

Organoleptic properties are fundamental in the plant domestication. Ankli et al. (1999b) and Brett and Heinrich (1998) reported that the organoleptic characteristics

Table 5 Compounds, taxa, and management category considered in the study. (+) presence or (-) absence of the compounds

\begin{tabular}{|c|c|c|c|c|}
\hline \multirow[t]{2}{*}{ Compounds } & \multicolumn{2}{|l|}{ A. mexicana } & \multirow{2}{*}{$\begin{array}{l}\text { A.m. subsp. xolocotziana } \\
\text { Cultivated }\end{array}$} & \multirow{2}{*}{$\begin{array}{l}\text { A. palmeri } \\
\text { Tolerated }\end{array}$} \\
\hline & Cultivated & Encouraged & & \\
\hline Estragole & + & - & + & - \\
\hline Geraniol & + & + & + & + \\
\hline Linalool & + & - & + & - \\
\hline Menthone & + & - & + & + \\
\hline Pulegone & + & + & + & + \\
\hline
\end{tabular}


Table 6 Domestication indicators in A. mexicana and A. m. subsp. xolocotziana

Evidences
Ethnobotany: traditional knowledge and selection criteria according to human use and management:
Traditional recognition
Plants known in cultivationas house plants
Distinguished by smell and taste
Morpho-physiologically distinguished
Preferred to treat ailments
Mainly vegetative propagation
Morpho-physiological:
Significant differences
Gigantism in used parts
Gigantism in correlated structures
Phytochemicals:
Differentiation in the composition of compounds in the essential oil
Differentiation related to human use and management

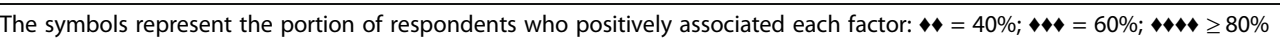

(mainly the aroma) of the plants are an important factor to determine them as medicinal, using them to define the relief ailment [18, 49]. Our work illustrates how these characteristics can also be fundamental in the process of domestication of aromatic medicinal plants, particularly in the hyssops. The people interviewed (Ozumba and Milpa Alta) recognize in A. mexicana an organoleptic differentiation between the plants encouraged, with a mild smell and flavor, and those cultivated, with an odor and sweet anise taste, relating the latter with greater effectiveness to alleviate different ailments, including gastrointestinal. At the same time, this is reflected in the phytochemical analysis where the cultivated hyssop has five aromatic compounds compared with the encouraged hyssop with only three aromatic compounds available (Table 5).

The morpho-physiological evidence indicates significant differences in floral, seed, and vegetative characteristics between the encouraged and cultivated plants of $A$. mexicana (Table 3). Flower size and corolla pigmentation were larger and more intense, respectively, in the cultivated populations. These characters are important selection criteria because the floral stage of Agastache is preferred state for consumption and is considered most effective as herbal remedy; hence, the cultivated category is the most appreciated.

Seed size was also larger in cultivated plants than in encouraged A. mexicana plants. However, ethnobotanical and physiological data show that this character is not directly selected. The interviewees mentioned that generally "all seeds germinate" and the physiological evaluation shows that there are no significant differences in the percentage of germination of the same; hence, the gigantism of this character is probably linked to the size of other related structures, possibly the largest size of the flower in cultivated plants.

As for the vegetative characters, the cultivated $A$. mexicana have a larger leaf size, a feature readily selected visually as being a valued trait of biomass yield. These characteristics were also found in the incipient domestication of cultivated epazote, selected for consumption as a condiment and as a medicinal herb [22]. Also, a greater number of nodes are found in the rhizome of the cultivated plants than those of the encouraged $A$. mexicana. This feature is related to its management, since vegetative propagation is preferred. Also, the increase of meristematic sites on the rhizome produces more stems that can be harvest.

In addition, significant differences were found in the total height and in the size of the inflorescence, being greater in the encouraged than in the cultivated ones of A. mexicana, opposite to the expected result, considering that those characteristics are subject to selection. These results may be associated with management, taking into account that the people interviewed mentioned that the plants developed from seeds in their first flowering period, "they do not grow much." However, as time passes, the rhizome is strengthened and produces taller plants with larger inflorescences than those encouraged, explaining why the cultivation of these plants is mainly asexual.

When combining the three classes of evidence obtained in $A$. mexicana, a domestication syndrome is observed that consists of an organoleptic differentiation (smell and taste "sweet aniseed") related to a 
phytochemical differentiation, floral gigantism, intensification of pigmentation, seed gigantism, and rhizome gigantism (enabling greater asexual reproductive capacity).

With respect to the origin of subsp. xolocotziana, the ethnobotanical, morpho-physiological, and phytochemical results clearly distinguish it from its putative parents, A. mexicana and A. palmeri, reflecting a series of domestication trends (Table 6). First, the organoleptic characteristics (mild mentholated) are very important for the traditional recognition of the subsp. xolocotziana in plantlet stage, since in its floral stage its differentiation is also based on the white color of the flower. The phytochemical differentiation is manifested by the presence of all five aromatic compounds analyzed (Table 5).

In morpho-physiological terms, flower color of the subsp. xolocotziana (white) was different compared to $A$. mexicana (purple) and A. palmeri (pink). Obviously, this trait is the basis of the folk nomenclature as well as recognition for selection during the floral stage and at the same time makes the plants more attractive to the consumer (Table 4 and Table 6).

The larger floral structures (size of the corolla, tube, style, and stamens) of the subsp. xolocotziana compared to $A$. mexicana (encouraged) and A. palmeri indicate gigantism in the flower (Table 4). Gigantism in this structure was also found in the cultivated plants of $A$. mexicana. In both taxa, the flowers are subject to selection, since they are a very important character for their medicinal consumption, where they are used together to potentiate their calming effect, as well as recognition by consumers [13, 31, 40].

Contrary to expectations, inflorescences of subsp. xolocotziana are smaller size (due to fewer number of nodes and of flowers) compared to their putative parents (Table 4). Some vegetative characters, such as the total height and area of the leaf (linked to a smaller number of teeth on the leaf) were also found to be reduced in this subspecies. Probably, as in the case of cultivated plants of $A$. mexicana, this is due to the plants being produced by seeds that reached only their first flowering period under experimental conditions. However, the people interviewed mention that of the harvest of subsp. xolocotziana is less than that of cultivated A. mexicana. It may be that dwarfism in these plants may represent depression.

The seeds also present gigantism in the subsp. xolocotziana; however, they are partially sterile, given the low percentage of germination found $(30 \%)$ and the ethnobotanical information registered. In this sense, the gigantism in this structure is not related to its viability but may be linked to the gigantism present in the flower.

The rhizome-related characters in this subspecies also show significant differences when compared to the other two taxa, indicating gigantism with its longer rhizomes with a greater number of nodes (Table 4). These features are directly related to its management. Not only do these rhizomes facilitate rapid, one-step vegetative planting but also permit greater production of harvestable stems. A similar result was observed in cultivated plants of Manihot esculenta in which there was a greater production of propagules compared to their wild relatives [55].

The domestication syndrome of the subsp. xolocotziana combines elements of organoleptic and phytochemical differentiation, floral gigantism, floral albinism, seed gigantism, and rhizome gigantism. This latter feature offsets the disadvantage of seed sterility so as to favor cloning of a novel, desirable form of Agastache.

The morpho-physiological evidence shows a divergence of $A$. mexicana (encouraged) toward the subsp. xolocotziana (Fig. 3). Two major explanations may account for this situation. On the one hand, inbreeding depression in the typical $A$. mexicana may have given rise to the subsp. xolocotziana. In the populations of plants where disruptive evolutionary force operates, divergence can produce populations with lower fitness, which is expressed in its reduced vigor and fertility [56, 57]. These particularities are reflected in this taxon with less vigorous structures, lower germination percentage, and lower number of flowers produced (Table 4).

On the other hand, Abbott et al. [58] (2013) report that hybrids may not be morphologically and genetically intermediate to their parents, since one parent is dominant that it is difficult to detect the other in the hybrid. In this sense, this work does not rule out the hypothesis of the possible hybrid origin of the subsp. xolocotziana, since possibly $A$. mexicana has a morphological and genetic dominance over this subspecies.

In phytochemical terms, hybrids usually present additive, shared, and new compounds [59]. Based on this, the subsp. xolocotziana shows additivity in the menthone compound, and two shared compounds geraniol and pulegon with the possible parents (Table 5). In addition, Estrada-Reyes et al. (2004) reported the presence of 27 new compounds in the subsp. xolocotziana when compared with $A$. mexicana. It should be noted that in our work it was not possible to detect more compounds by the method used (TLC). Another novel character in this taxon is the white color of the flower; this particularity for instance has been found in the flowers of strawberry hybrids (Fragaria sp.) [60]. Also, partially sterile seeds are a trait of plants with a hybrid origin [61].

In order to clarify the origin of subsp. xolocotziana, phytochemical (more detailed gern technique) and genetic (phylogenetic and population genetics) studies of plant populations studied will provide more specific information about these two hypotheses. 


\section{Maintenance strategies of cultivated germplasm}

As for the encouraged populations of $A$. mexicana, they are found only on the periphery of the milpa agroecosystem, because in these places the inhabitants foster, maintain, and select "toronjil" for domestic use (medicinal and esthetic). Our study did not locate wild populations of this taxon in sites where it grew in 1980s [29]. Hence, the traditional management that the inhabitants of Milpa Alta provide in their milpa is as an important conservation mechanism for the permanence of this species.

In addition, the introduction of plants originating from seeds of $A$. mexicana crops is an important management and conservation strategy for these populations, since it has been reported that this practice helps maintain and generate genetic variability in vegetatively propagated crops $[55,62,63]$.

Our ethnobotanical research indicates that the subsp. xolocotziana has high sensitivity to extreme environmental changes. Considering that it is known only from cultivation of mostly clonal plants, and that it exhibits partially sterile seeds, favoring the most vigorous individuals produced from seeds is fundamental for the conservation of this taxon. Several studies have documented that this type of management in vegetatively propagated crops can significantly increase their genetic diversity, making crops more resistant to environmental changes, such as agaves (Agave angustifolia Haw.) and cassava (Manihot esculenta Crantz) [55, 63-65].

\section{Conclusions}

The evidence obtained indicates two divergent evolutionary processes under domestication. First, populations of A. mexicana growing in central Mexico are positioned medially along the domestication gradient and express elements of a domestication syndrome including organoleptic differentiation related to a phytochemical differentiation, floral gigantism, pigment intensification, seed gigantism, and rhizome gigantism. Second, A. m. ssp. xolocotziana, possibly originated by inbreeding depression or hybridization, demonstrates a syndrome with organoleptic and phytochemical differentiation, floral gigantism, albiflorism, seed gigantism, and rhizome gigantism. Each process has distinctive elements that make up its domestication syndrome which coincide with their importance in MTM to impart a calming effect in treating various ailments.

\section{Acknowledgement}

To the inhabitants of the municipalities of Ozumba (Edomex), Milpa Alta (CDMX) and to those of Nicolás Flores (Hgo.), for their valuable information. To PhD Manuel Jesús Cach Pérez for his company in the field, and to PhD Andrea Martínez Ballesté and two anonymous reviewers for their comments.

\section{Authors' contributions}

GCG contributed to the design of the project, to obtain financing, collected and analyzed the data, coordinated the writing and editing of the manuscript. RB designed the project, obtained the financing, contributed to the data analysis, and coordinated the writing and editing of the manuscript. LE contributed in the data analysis, writing, and editing of the manuscript. SC contributed in the writing, and editing of the manuscrip and together with PPL contributed to the data collection and phytochemical analysis. FVS and MLC contributed to the writing of the manuscript. All authors read and approved the final manuscript.

\section{Funding}

This study was supported, in part, by Posgrado en Ciencias

Biológicas-Universidad Nacional Autónoma de México (UNAM), the

Programa de Apoyo a Proyectos de Investigación e Innovación Tecnológica (PAPIIT-UNAM-project IN202015) and the Consejo Nacional de Ciencia y Tecnología (CONACYT) which provided a graduate scholarship to GCG.

\section{Availability of data and materials}

Please contact first author for data requests.

\section{Ethics approval and consent to participate}

Prior to the research, the authorities of each locality were contacted to present the project along with an institutional letter and the federal collecting permit and to request their authorization to carry it out the study. Subsequently, we located the people who manage these resources and explained the project in detail; once they agreed to participate, we proceeded to take data (ethnobotanicals, plant collections, herbarium specimens, photographs). All the information presented here was obtained under the prior, informed consent of authorities and residents of each locality. The national permit was issued by Mexico's Subsecretaria de Gestión para la Protección Ambiental under the certificate SGPA/DGGFS/712/2658/ 18.

Consent for publication

No applicable.

\section{Competing interests}

The authors declare that they have no competing interests.

\section{Author details}

${ }^{1}$ Posgrado en Ciencias Biológicas, Jardín Botánico, Instituto de Biología, Universidad Nacional Autónoma de México, Ciudad Universitaria, Ciudad de

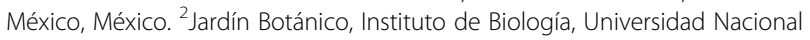
Autónoma de México, Ciudad Universitaria, Ciudad de México, México. ${ }^{3}$ Departamento de Ecología Evolutiva, Instituto de Ecología, Universidad Nacional Autónoma de México, Ciudad Universitaria, Ciudad de México, México. ${ }^{4}$ Facultad de Ciencias, Universidad Nacional Autónoma de México, Ciudad Universitaria, Ciudad de México, México. ${ }^{5}$ Posgrado en Botánica, Colegio de Posgraduados, Campus Montecillo, Texcoco, Estado de México, México.

Received: 13 February 2020 Accepted: 6 April 2020

Published online: 01 May 2020

\section{References}

1. Gepts P. Crop domestication as a long-term selection experiment. Plant Breed. 2004;24:1-44 Available from: http://www.plantsciences.ucdavis.edu/ GEPTS/LTS.pdf.

2. Bye R. Quelites: ethnoecology of edible plants_-past, present and future. J Ethnobiol. 1981;1:109-23 Available from: https://ethnobiology.org/ journal/\%5Bfield_volume-raw\%5D-38.

3. Rendón B, Nuñez-Farfán J. Population differentiation and phenotypic plasticity of wild and agrestal populations of the annual Anoda cristata (Malvaceae) growing in two contrasting habitats. Plant Ecol. 2001;156:20513 Available from: https://doi.org/10.1023/A:1012657730991.

4. Miller A, Schaal B. Domestication of a Mesoamerican cultivated fruit tree, Spondias purpurea. Proc Natl Acad Sci U S A. 2005;102:12801-6 Available from: https://www.pnas.org/content/102/36/12801.short.

5. Arias D, Peñaloza-Ramírez J, Dorado O, Cuevas-Reyes $P$, Leyva E, AlbarránLara AL, et al. Phylogeographic patterns and possible incipient domestication of Jacaratia mexicana A. DC. (Caricaceae) in Mexico. Genet Resour Crop Evol. 2010;57:1227-38 Available from: http://link.springer.com/1 0.1007/s10722-010-9569-1. 
6. Zizumbo-Villarreal D, Flores-Silva A, Colunga-García MP. The archaic diet in Mesoamerica: incentive for milpa development and species domestication. Econ Bot. 2012;66:328-43 Available from: http://link.springer.com/10.1007/ s12231-012-9212-5.

7. Casas A, Blancas, J, Otero-Arnaiz A, Cruse-Sanders J, Lira R, Avendaño A, Parra F., Guillén S., Fiqueredo C., Torres I, Rangel-Landa S. Evolutionary ethnobotanical studies of incipient domestication of plants in mesoamerica. In: Lira, R., Casas, A, Blancas J, editors. Ethnobotany of Mexico. Springer; 2016. p. 1-19. Available from: https://www.springer.com/gp/book/ 9781461466680

8. Griffith PM. The origins of an important cactus crop, Opuntia ficus-indica (Cactaceae): new molecular evidence. Am J Bot. 2004;91:1915-21 Available from: https://doi.org/10.3732/ajb.91.11.1915.

9. Hughes CE, Govindarajulu R, Robertson A, Filer DL, Harris SA, Bailey CD. Serendipitous backyard hybridization and the origin of crops. Proc Natl Acad Sci U S A. 2007;104:14389-94 Available from: https://doi.org/10.1073/ pnas.0702193104.

10. Gentry HS. Agaves of continental North America. Tucson, USA: University of Arizona Press; 1982. Available from: https://books.google.com.mx/books?hl=

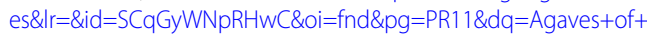
Continental+North+America\&ots=lodanU-SX4\&sig=Ekt2ysOw3Fyr6 rgolOwERvXKK4Y\&redir_esc=y\#v=onepage\&q=Agaves\%20of\%2 oContinental\%20North\%20America\&f=false.

11. Purugganan MD. Evolutionary insights into the nature of plant domestication. Curr Biol Cell Press. 2019;29:R705-14 Available from: https:// www.sciencedirect.com/science/article/pii/S0960982219306232.

12. Hammer K. Das domestikationssyndrom. Kulturpflanze. 1984;32:11-34. Available from: https://doi.org/10.1007/BF02098682.

13. Bye $R$, Linares $E$, Estrada E. Biological diversity of medicinal plants in Mexico. In: Arnason JT, Mata R, Romeo JT, editors. Phytochemistry of Medicinal Plants. New York.: Plenum Press; 1995. p. 65-82. Available from: https:// books.google.com.mx/books?hl=es\&lr=\&id=KwvyBwAAQBAJ\&oi=fnd\&pg= PA2\&dq=arnason+Phytochem+Med+Plants\&ots=PoXzc51-3q\&sig= HkeZAQ8odIOFOHEQnXg2kio85tI\&redir_esc=y\#v=onepage\&q=arnason\%2 OPhytochem\%20Med\%20Plants\&f=false.

14. González-Stuart A, Rivera J. Comparison of herbal products use in two largest border communities between the US and Mexico. Herbalgram. 2009; 81:58-66 Available from: http://cms.herbalgram.org/herbalgram/issue81/ article3378.html.

15. Leonti M. The future is written: impact of scripts on the cognition, selection, knowledge and transmission of medicinal plant use and its implications for ethnobotany and ethnopharmacology. J Ethnopharmacol. 2011;134:542-55 Available from: https://www.sciencedirect.com/science/article/pii/S03 78874111000183.

16. Heinrich M. Indigenous concepts of medicinal plants in Oaxaca, Mexico: lowland mixe plant cassification based on orgaleptic characteristics. Angew Bot. 1998;72:75-81 Available from: https://www.researchgate.net/ publication/228326866_Indigenous_concepts_of_medicinal_plants_in_ Oaxaca_Mexico_Lowland_Mixe_plant_classification_based_on_ organoleptic_characteristics.

17. Casagrande D. Human taste and cognition in Tzeltal Maya medicinal plant use. J Ecol Anthropol. 2000;4:57-69 Available from: https://www. researchgate.net/publication/271320980_Human_Taste_and_Cognition_in_ Tzeltal_Maya_Medicinal_Plant_Use.

18. Ankli A, Sticher O, Heinrich M. Yucatec Maya medicinal plants versus nonmedicinal plants: Indigenous characterization and selection. Hum Ecol. 1999:27:557-80 Available from: https://link.springer.com/article/10.1023/A:1 018791927215.

19. Ankli A, Sticher O, Heinrich M. Medical ethnobotany of the Yucatec Maya: healers' consensus as a quantitative criterion. Econ Bot. 1999;53:144-60 Available from: https://link.springer.com/article/10.1007/BF02866493.

20. Geck MS, Cabras S, Casu L, Reyes García AJ, Leonti M. The taste of heat: how humoral qualities act as a cultural filter for chemosensory properties guiding herbal medicine. J Ethnopharmacol. 2017a;198:499-515 Available from: https://www.sciencedirect.com/science/article/pii/S037887411630770X.

21. Geck MS, Cabras S, Casu L, Reyes García AJ, Leonti M. The taste of heat: how humoral qualities act as a cultural filter for chemosensory properties guiding herbal medicine. J Ethnopharmacol. 2017b;198:499-515 Available from: https://doi.org/10.1016/j.jep.2017.01.027.

22. Blanckaert I, Paredes-Flores M, Espinosa-García FJ, Piñero D, Lira R. Ethnobotanical, morphological, phytochemical and molecular evidence for the incipient domestication of epazote (Chenopodium ambrosioides $L$.: Chenopodiaceae) in a semi-arid region of Mexico. Genet Resour Crop Evol. 2012;59:557-73. Available from: https://doi.org/10.1007/s10722-011-9704-7.

23. Martínez-Natarén DA, Parra-Tabla V, Ferrer-Ortega MM, Calvo-Irabién LM. Genetic diversity and genetic structure in wild populations of Mexican oregano (Lippia graveolens H.B.K.) and its relationship with the chemical composition of the essential oil. Plant Syst Evol. 2014;300:535-47. Available from: https://doi.org/10.1007/s00606-013-0902-y.

24. Bagheri R, Dehdari M, Salehi A. Effect of cold stress at flowering stage on some important characters of five German chamomile (Matricaria chamomilla L.) genotypes in a pot experiment. J Appl Res Med Aromat Plants. 2019 100228. Available from: https://www.sciencedirect.com/science/ article/pii/S2214786119305091.

25. Carrillo-Galván G, Bye R, Eguiarte L. Domesticación de plantas medicinales aromáticas. In: Casas A, Torres-Guevara J, Parra-Rondinel F, editors. Domest en el Cont Am. Lima, Perú: UNAM-UNALM; 2017. p. 431-49.

26. Colunga-GarcíaMarín P, May-Pat F. Morphological variation of henequén (Agave fourcroydes, Agavaceae) germplasm and its wild ancestor (A angustifolia ) under uniform growth conditions: diversity and domestication. Am J Bot 1997;84:1449-1465. Available from: http://doi.wiley.com/10.23 $07 / 2446608$.

27. Bye R, Linares E, Ramamoorthy TP, García F, Collera O, Palomino G, Corona V. Agastache mexicana subsp. xolocotziana (Lamiaceae), new taxon from the Mexican medicinal plants. Phytologia. 1987;62:157-63 Available from: https://www.biodiversitylibrary.org/item/47365\#page/3/mode/1 up.

28. Carvajal N. Aportación de las plantas medicinales silvestres de una zona de Milpa Alta, al mercado de Sonora, Distrito Federal, México. Mexico, DF: Universidad Nacional Autónoma de México; 2006. p. 92. Available from: http://132.248.9.195/pd2006/0604185/Index.html.

29. Linares $\mathrm{E}$, Bye R. La dinámica de un mercado periférico de plantas medicinales de México: el tianguis de Ozumba, Estado de México, como centro acopiador para el mercado de Sonora (mercado central). In: Long J, Attolini A, editors, Caminos y Mercados de México. Universidad Nacional Autónoma de México; 2009. p. 631-63. Available from: http://www.historicas unam.mx/publicaciones/publicadigital/libros/caminosymercados/cm031.pdf.

30. Sanders RW. Taxonomy of Agastache Section Brittonastrum ( LamiaceaeNepeteae ). Syst Bot Monogr. 1987;15:1-92 Available from: https://www. jstor.org/stable/25027677.

31. Estrada-Reyes R, Aguirre Hernández E, García-Argáez A, Soto Hernández M, Bye R, Linares E, Heinze G, Martínez-Vázquez M. Comparative chemical composition of Agastache mexicana subsp. mexicana and A. mexicana subsp. xolocotziana. Biochem Syst Ecol. 2004;32:685-94. Available from: https://doi. org/10.1016/j.bse.2004.01.005.

32. Heinrich M, Frei Haller B, Leonti M. A perspective on natural products research and ethnopharmacology in Mexico: the eagle and the serpent on the prickly pear cactus. J Nat Prod. 2014;77:678-89. Available from: https:// doi.org/10.1021/np4009927.

33. Santillán MA, López ME, Aguilar S, Aguilar A. Estudio etnobotánico, arquitectura foliar y anatomía vegetativa de Agastache mexicana ssp. mexicana y A. mexicana ssp. xolocotziana. Rev Mex Biodivers. 2008;79:513-24 Available from: http://www.scielo.org.mx/scielo.php?script=sci_ abstract\&pid=S1870-34532008000200024\&lng=en\&nrm=iso\&tlng=en.

34. Linares E, Bye R. Códice De la Cruz-Badiano (Segunda parte). Arqueol Mex. 2013;51:1-93.

35. Bye R, Linares E. Códice De la Cruz-Badiano (Primera parte). Arqueol Mex. 2013:50:1-91.

36. De la Cruz M, Badiano J. Libellus de medicinalibus indorum herbis. Manuscrito azteca de 1552. Según traducción latina de Juan Badiano. Instituto Mexicano del Seguro Social.: México; 1964.

37. Hernández F. Historia Natural de Nueva Espafia. México, D.F.: Universidad Nacional Autónoma de México; 1959.

38. Martínez M. Las Plantas Medicinales en México. Ediciones Botas: México; 1990.

39. Argueta A, Cano L, Rodarte M. Atlas de las Plantas de la Medicina Tradicional Mexicana. México, D.F.: Instituto Nacional Indigenista Press; 1994.

40. Estrada-Reyes R, López-Rubalcava C, Ferreyra-Cruz OA, Dorantes-Barrón A, Heinze G, Moreno Aguilar J, et al. Central nervous system effects and chemical composition of two subspecies of Agastache mexicana; an ethnomedicine of Mexico. J Ethnopharmacol. 2014;153:98-110 Available from: https://doi.org/10.1016/j.jep.2013.12.057. 
41. González-Ramírez A, González-Trujano M, Pellicer F, López-Muñoz F. Antinociceptive and anti-inflammatory activities of the Agastache mexicana extracts by using several experimental models in rodents. J Ethnopharmacol. 2012;142:700-5. Available from: https://doi.org/10.1016/j. jep.2012.05.044.

42. Verano J, Gonzáez-Trujano M, Déciga-Campos M, Ventura-Martínez R. Pellicer. Ursolic acid from Agastache mexicana aerial parts produces antinociceptive activity involving TRPV1 receptors, cGMP and a serotonergic synergism. Pharmacol Biochem Behav. 2013;110:255-64 Available from: https://doi.org/10.1016/j.pbb.2013.07.020.

43. Ávila N. Determinación del mecanismo de acción relajante del aceite esencial de Toronjil morado (Agastache mexicana), en la musculatura lisa bronquial de cobayo. Mexico, DF: Universidad Nacional Autónoma de México; 2013. p. 12-5. Available from: https://www.zaragoza.unam.mx/ portal/wp-content/Portal2015/Licenciaturas/gfb/tesis/tesis_avila_rosas.pdf.

44. Cortés-Zamora A, Verano J. Evaluación del efecto antinociceptivo de extractos organicos y metabolitos activos de Agastache mexicana ssp. xolocotziana en ratones. Mexico, DF: Universidad Nacional Autónoma de México; 2010. Available from: www.revistas.unam.mx/index.php/repiwww. iztacala.unam.mx/carreras/psicologia/psiclin.

45. Chavarría-Ramírez J, Rivas-Falcón J. Evaluación del efecto anticonvulsivo del extracto hidroalcohólico de Agastache mexicana (Kunth) Lint \& Epling ssp. xolocotziana (toronjil blanco), Dracocephalum moldavica L. (toronjil azul), Agastache mexicana (Kunth) Lint \& Epling (toronjil morado) y de su mezcla. Mexico, DF: Universidad Nacional Autónoma de México; 2012. Available from: http://oreon.dgbiblio.unam.mx/F/SS8SMDP6QJ23C6GD8TUN6FT5T6 7CJUGTGU8STTG6FH4G611QUM-24762?func=full-set-set\&set_number=0222 $75 \&$ set_entry $=000005 \&$ format $=999$.

46. Bye $R$, Linares E. Perspectives on ethnopharmacology in Mexico. In: Heinrich M, Jager A, editors. Ethnopharmacol. Chichester, UK: John Wiley \& Sons; 2015. p. 393-404. Available from: https://onlinelibrary.wiley.com/doi/book/1 $0.1002 / 9781118930717$

47. INEGI. Instituto Nacional de Estadística y Geografía. México. 2010.

48. Jalpa T. Ozumba: de la marginación a la pujanza. In: Spencer M, editor. Ozumba arte e Hist. Primera Ed. México: Fondo Editorial del Estado de México; 2014. p. 11-43. Available from: https://ceape.edomex.gob.mx/ content/ozumba-arte-e-historia.

49. Brett J, Heinrich M. Culture, perception and the environment: the role chemosensory perception. Angew Bot. 1998;72:67-9 Available from: https:// www.researchgate.net/publication/279599442_Culture_perception_and_ the_environment_The_role_of_chemosensory_perception.

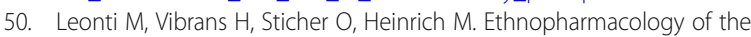
Popoluca, Mexico: an evaluation. J Pharm Pharmacol. 2001;53:1653-69. Available from: https://doi.org/10.1211/0022357011778052.

51. Goodman LA. Snowball Sampling. Ann Math Stat. 1961;32:148-70 Available from: https://www.jstor.org/stable/2237615.

52. R Core Team. R: A language and environment for statistical computing. Viena, Austria: R Foundation for Statistical Computing; 2019. Available from: https://repo.bppt.go.id/cran/web/packages/dplR/vignettes/intro-dplR.pdf.

53. Said HAH, Sabra AS, Nasser A, El Gendy G, Aziz EE, et al. Changes in content and chemical composition of Dracocephalum moldavica L. essential oil at different harvest dates. J Med Plants Stud. 2015;3:61-4 Available from: https://www.researchgate.net/profile/Hussein_Said-Al_Ahl2/publication/2743 74574_Changes_in_content_and_chemical_composition_of_ Dracocephalum_moldavica_L_essential_oil_at_different_harvest_dates/ links/551c61920cf20d5fbde53f9a.pdf.

54. Comision Permanente de la FarrFarmacopea Herbolaria de los Estados Unidos Mexicanos. Farmacopea Herbolaria de los Estados Unidos Mexicanos. Mexico, DF: Secretaría de Salud; 2014.

55. Elias M, Penet L, Vindry P, McKey D, Panaud O, Robert T. Unmanaged sexual reproduction and the dynamics of genetic diversity of a vegetatively propagated crop plant, cassava (Manihot esculenta Crantz), in a traditional farming system. Mol Ecol. 2001;10:1895-907 Available from: https://doi.org/ 10.1046/j.0962-1083.2001.01331.x.

56. Norman JK, Sakai AK, Weller SG, Dawson TE. (Caryophyllaceae) in Two Environments. Evolution. 1995;49:297. Available from: https://doi.org/10. 1111/j.1558-5646.1995.tb02242.x.

57. Charlesworth $\mathrm{D}$, Willis $\mathrm{JH}$. The genetics of inbreeding depression. Nat Rev Genet. 2009;10:783-96 Available from: https://doi.org/10.1038/nrg2664.
58. Abbott R, Albach D, Ansell S, Arntzen JW, Baird SJE, Bierne N, et al. Hybridization and speciation. J Evol Biol. 2013;26:229-46. Available from: https://doi.org/10.1111/j.1420-9101.2012.02599.x.

59. Kadereit JW. The geography of hybrid speciation in plants. Taxon. 2015;64: 673-87 Available from: https://doi.org/10.12705/644.1.

60. Xue L, Wang Z, Zhang W, Li Y, Wang J, Lei J. Flower pigment inheritance and anthocyanin characterization of hybrids from pink-flowered and whiteflowered strawberry. Sci Hortic (Amsterdam). 2016;200:143-50. Available from: https://www.sciencedirect.com/science/article/abs/pii/S03044238163 $0022 X$.

61. Grant V. Plant speciation. New York: Columbia University Press; 1981.

62. Olsen KM, Schaal B. Insights on the evolution of a vegetatively propagated crop species. Mol Ecol. 2007;16:2838-40. Available from: https://doi.org/10. 1111/j.1365-294X.2007.03359.x.

63. McKey D, Elias M, Pujol ME, Duputié A. The evolutionary ecology of clonally propagated domesticated plants. New Phytol. 2010;186:318-32. Available from: https://doi.org/10.1111/j.1469-8137.2010.03210.x.

64. Elias M, Lenoir H, McKey D. Propagule quantity and quality in traditional Makushi farming of cassava (Manihot esculenta): a case study for understanding domestication and evolution of vegetatively propagated crops. Genet Resour Crop Evol. 2007;54:99-115. Available from: https://doi. org/10.1007/s10722-005-2022-1.

65. Vargas-Ponce O, Zizumbo-Villarreal D, Colunga-GarcíaMarín P. In situ diversity and maintenance of traditional agave landraces used in spirits production in West-Central Mexico. Econ Bot. 2007;61:362-75. Available from: https://doi.org/10.1663/0013-0001(2007)61[362:ISDAMO]2.0.CO;2.

\section{Publisher's Note}

Springer Nature remains neutral with regard to jurisdictional claims in published maps and institutional affiliations.

Ready to submit your research? Choose BMC and benefit from:

- fast, convenient online submission

- thorough peer review by experienced researchers in your field

- rapid publication on acceptance

- support for research data, including large and complex data types

- gold Open Access which fosters wider collaboration and increased citations

- maximum visibility for your research: over $100 \mathrm{M}$ website views per year

At BMC, research is always in progress.

Learn more biomedcentral.com/submissions 